\title{
UPAYA PENINGKATAN PRODUKTIVITAS DALAM USAHA PEMBESARAN UDANG GALAH (Macrobrachium rosenbergii de Man)
}

\author{
Ikhsan Khasani*) \\ *) Loka Riset Pemuliaan dan Teknologi Budidaya Perikanan Air Tawar, Sukamandi
}

\begin{abstract}
ABSTRAK
Budidaya udang galah mengalami perkembangan yang cukup pesat, khususnya pada sektor pembesaran. Namun demikian, pada kondisi di lapangan masih sering muncul berbagai kendala, disebabkan belum tersosialisasikan sistem budidaya dan kurangnya penguasaan teknologi spesifik dalam budidaya udang galah. Oleh karena itu, sosialisasi teknologi tepat guna dalam mendukung perkembangan udang galah menjadi hal yang sangat penting dalam rangka lebih dimengertinya sistem budidaya udang galah. Upaya peningkatan produktivitas dalam usaha pembesaran udang galah dapat dilakukan dengan penerapan intensivikasi pemeliharaan dan pengembangan sentra budidaya.
\end{abstract}

KATA KUNCl: produktivitas, udang galah, intensivikasi, sentra budidaya

\section{PENDAHULUAN}

Udang galah merupakan komoditas perikanan air tawar yang sangat potensial untuk dibudidayakan secara komersial (New, 2002). Pertumbuhan yang cepat, ukuran yang besar, tingkat prevalensi penyakit yang rendah, dan permintaan pasar yang luas, baik pasar domestik maupun ekspor, merupakan potensi yang menjadikan komoditas ini memegang peran penting dalam usaha budidaya perikanan air tawar di Indonesia. Sosialisasi prospek dan teknologi budidaya melalui berbagai media ternyata cukup efektif dalam mendorong perkembangan komoditas yang mendapat sebutan Baby Lobster ini. Perkembangan yang sangat menggembirakan adalah dengan dibukanya kawasan budidaya dalam luasan yang besar mencapai 500 ha di Muara Enim (Palembang) dan Kepulauan Riau yang diharapkan dapat mendongkrak citra udang tawar hingga mampu sejajar dengan komoditas udang payau, seperti udang vanamei dan udang windu.

Selain usaha pembesaran dalam skala besar oleh pengusaha dengan teknologi dan modal memadai, ternyata budidaya udang galah juga mulai menjadi alternatif pilihan bagi para pembudidaya ikan skala pedesaan di beberapa daerah seperti Kabupaten Pekalongan, Banyumas, Subang, Indramayu, Karawang, dan Bekasi. Keterbatasan pengetahuan mengenai bagaimana teknologi budidaya yang efektif dan ekonomis merupakan salah satu permasalahan yang perlu segera dipecahkan sehingga kegiatan budidaya yang sudah ada dapat lebih berkembang. Rangkaian langkah berikut merupakan solusi untuk menuju keberhasilan usaha pembesaran udang galah, yaitu: optimalisasi kondisi kolam, penggunaan benih unggul, penggunaan naungan (shelter), monitoring kualitas air secara periodik, penyeragaman ukuran benih, pemeliharaan benih tunggal kelamin, penggunaan jenis pakan, dan sistem pemberian yang tepat, serta pengembangan sentra budidaya.

\section{OPTIMALISASI KONDISI KOLAM}

Udang galah merupakan biota air tawar yang sangat sensitif terhadap perubahan lingkungan sehingga memerlukan penanganan spesifik dalam pemeliharaannya. Kualitas air untuk budidaya udang galah dapat dikatakan harus lebih bagus dari komoditas ikan tawar lainnya, karena udang sangat sensitif dan mudah stres terhadap menurunnya kualitas air. Fenomena pergantian kulit (moulting), yang merupakan rangkaian proses udang untuk tumbuh (Mente, 2003; New \& Vallenti, 2004), berdampak pada melemahnya kondisi udang. Kondisi tersebut menyebabkan udang semakin sensitif terhadap menurunnya kualitas lingkungan hidupnya. Untuk memenuhi kebutuhan lingkungan optimal bagi kehidupan udang galah maka rangkaian pengolahan kolam harus dilakukan secara seksama.

Pengolahan dasar kolam merupakan langkah awal yang akan menentukan berhasil tidaknya kegiatan budidaya. Pengetahuan mengenai derajat keasaman tanah, komposisi dan tekstur tanah kolam akan sangat membantu dalam upaya pengolahan kolam. Secara umum udang lebih menyukai dasar kolam yang sedikit berlumpur dan tidak porous (Anonim, 2003). Lumpur yang dalam merupakan kondisi yang tidak menguntungkan sehingga pengangkatan lumpur dari dasar kolam, setelah satu siklus kegiatan pembesaran selama 4--6 bulan, merupakan kegiatan 
primer yang akan lebih menjamin keberhasilan usaha budidaya. Udang galah bersifat bentik (New, 2002), yaitu hidup di dasar kolam, sehingga udang akan mengkonsumsi pakan yang jatuh ke dasar. Cara udang mengambil pakan juga unik, yaitu dengan menggunakan kaki jalan kedua sehingga memerlukan waktu yang cukup lama dibandingkan dengan ikan pada umumnya. Kebiasaan hidup udang tersebut menjadikan lumpur kolam yang tebal sebagai masalah yang serius dalam usaha pemeliharaan udang galah. Kondisi lumpur dasar kolam yang tebal sangat menghambat pertumbuhan udang karena pakan yang lolos dan terjebak dalam lumpur akan mempercepat penimbunan bahan organik, yang disusul oleh proses biodegradasi oleh bakteri. Proses biodegradasi bahan organik akan menghasilkan senyawa racun, seperti amonia dan nitrit (Boyd, 1990; Cheng et al., 2002; Foss et al., 2003) yang membahayakan kehidupan udang. Bakteri pendegradasi bahan organik juga mengkonsumsi oksigen terlarut dalam jumlah yang besar, sehingga kondisi kualitas air kolam semakin menurun.

Dalam proses pengolahan dasar kolam, pengapuran juga sering kali harus dilakukan. Kegiatan pengapuran dilakukan setelah dasar kolam digemburkan dan diratakan. Pengapuran selain berfungsi untuk meningkatkan kebasaan kolam, supaya mencapai kondisi optimal $(\mathrm{pH}$ 7--8,5), juga berfungsi membunuh telur-telur ikan predator dan jamur. Dosis yang dianjurkan dalam kegiatan pengapuran adalah 600--1.000 kg/ha (Alimon, 2005).

Udang galah dengan beberapa tingkah laku khas, seperti gerakan yang lambat, kebiasaan makan yang lambat, dan proses moulting menjadikan banyak biota lain berpotensi sebagai kompetitor dan atau predator baginya. Oleh karena itu, pematang yang bersih akan membantu dalam mengontrol keberadaan predator, seperti ular, musang, dan burung. Pematang juga harus dipelihara dengan baik sehingga terhindar dari kebocorankebocoran, yang akan membuka peluang masuknya ikan yang dapat menjadi kompetitor atau pemangsa. Pada kolam pembesaran udang galah seringkali didapati berbagai jenis ikan, seperti nila, gabus, dan lele yang menyebabkan udang galah yang menjadikan derajat sintasan rendah.

Pemupukan merupakan proses penyediaan pakan alami bagi benih udang galah. Udang muda sampai dewasa memiliki kebiasaan mengaduk-aduk dasar kolam untuk mendapatkan makanan alami, seperti cacing dan kerangkerangan. Benih udang ukuran 1--3 gram ternyata tumbuh lebih cepat dalam kolam yang sebelumnya dilakukan pemupukan daripada kolam tanpa pemupukan (Khasani, 2004). Selain untuk menumbuhkan pakan alami, berupa fitoplankton dan zooplankton, pemupukan juga berfungsi mengurangi tingkat penetrasi cahaya matahari, sehingga dapat menghambat perkembangan lumut di dasar kolam, serta menciptakan lingkungan yang lebih kondusif bagi kehidupan udang, yang lebih menyukai daerah yang tersembunyi dan relatif gelap. Kegiatan pemupukan biasanya dilaksanakan 7--10 hari sebelum benih ditebar, dengan menggunakan kotoran ayam kering dengan dosis $100 \mathrm{~kg} / \mathrm{ha}$, yang diikuti $15 \mathrm{~kg} / \mathrm{ha}$ urea, dan $10 \mathrm{~kg} / \mathrm{ha}$ TSP (Alimon, 2005). Kompos dengan kualitas bagus dan siap digunakan juga telah beredar di pasaran kawasan Jabotabek. Kompos digunakan saat persiapan kolam dan beberapa kali pada satu bulan pertama masa pemeliharaan sehingga pakan alami, khususnya jasad bentik, tersedia di kolam. Berdasarkan pengalaman beberapa pembudidaya udang galah binaan LIPI Cibinong-Bogor, pemupukan dengan kompos komersial tersebut (Gambar 1) mampu menjamin ketersediaan pakan alami, sehingga dalam tahap pendederan dan pembesaran satu bulan awal tidak diperlukan pakan tambahan/buatan (Ali, 2004, komunikasi personal).

\section{PENGGUNAAN BENIH UNGGUL}

Benih memegang peranan yang sangat vital dalam menunjang keberhasilan kegiatan pembesaran udang galah. Secara umum, benih dikatakan unggul apabila

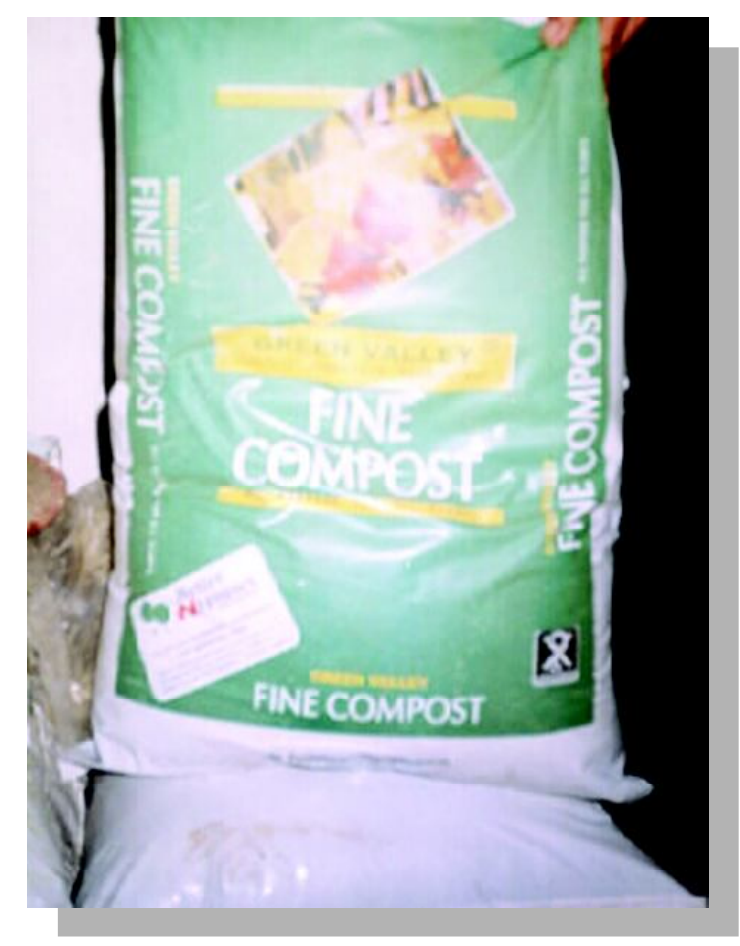

Gambar 1. Produk kompos kemasan, sebagai komponen pembuat air hijau dan penyediaan pakan alami 
memiliki tingkat pertumbuhan yang cepat, daya adaptasi lingkungan yang baik, serta memiliki tingkat ketahanan yang tinggi terhadap insidensi penyakit. Secara sederhana, untuk memperoleh benih unggul adalah dengan mengetahui asal induk yang digunakan dan sistem pembenihannya. Kenampakan visual benih yang baik adalah tidak cacat atau necrosis, dan lincah atau aktif berenang apabila dipindahkan ke wadah lain. Benih unggul akan lebih mudah diperoleh pada unit pembenihan dan pendederan dengan sarana yang memadai, dengan dukungan sumber daya pelaksana yang cakap. Hal tersebut, disebabkan pada sistem pemeliharaan intensif pakan yang diberikan memiliki kualitas baik.

Penggunaan benih yang sudah cukup umur, seperti yang dihasilkan dari kegiatan pendederan selama 30--60 hari (ukuran 1--5 gram) juga akan lebih menjamin keberhasilan dalam usaha pembesaran (Hadie $\&$ Hadie, 1997). Benih dengan ukuran tersebut akan lebih mampu beradaptasi terhadap perubahan lingkungan, serta lebih memiliki kemampuan menghindar dari predator dibandingkan benih dengan ukuran yang lebih kecil (PL-15).

Benih juga dinyatakan lebih baik kualitasnya apabila memiliki ukuran seragam. Benih dengan ukuran yang seragam diharapkan memiliki kemampuan yang sama dalam mendapatkan pakan, sehingga dapat dicapai ukuran panen yang seragam pula. Biasanya benih dengan ukuran tebar lebih besar akan cenderung tumbuh lebih cepat, sehingga memacu munculnya sifat kanibalisme terhadap benih dengan ukuran lebih kecil.

\section{PENGGUNAAN SUBSTRAT BUATAN}

Dalam usaha pendederan dan pembesaran udang galah, keberadaan tempat naungan, atau shelter, bagi udang galah sangat penting. Shelter diperlukan untuk persembunyian udang yang sedang moulting, sehingga mampu mengurangi tingkat kanibalisme, dan memperluas area untuk udang menempel. Ketika kadar oksigen terlarut di dasar kolam sangat rendah, shelter juga sangat diperlukan oleh udang. Pada kondisi tersebut, sebagian besar udang akan berada di permukaan shelter yang dekat permukaan air, sehingga udang dapat memperoleh lingkungan dengan kandungan kadar oksigen terlarut lebih tinggi.

Bentuk dan bahan shelter cukup beragam. Umumnya petani menggunakan pelepah daun kelapa atau pohon palem sebagai shelter. Namun demikian, penggunaan shelter dari daun kelapa dan palem dirasa kurang bagus. Bahan tersebut cepat busuk sehingga berpotensi mengotori kolam, mudah tenggelam sampai dasar kolam sehingga akan tertimbun oleh endapan lumpur, serta kurang efektif dalam menyediakan ruang yang nyaman bagi udang yang berganti kulit. Berdasarkan serangkaian penelitian dan pengujian, sekarang telah diperoleh tipe shelter yang optimal dalam pemeliharaan udang galah, yaitu shelter tipe bertingkat atau dikenal sebagai appartement shelter. Menurut Ali, Komunikasi personal (2004), pemeliharaan udang galah di kolam dengan luasan $500 \mathrm{~m}^{2}$, yang di dalamnya ditempatkan shelter bambu bentuk apartemen, telah berhasil diperoleh hasil panen udang galah sebanyak $350 \mathrm{~kg}$, dengan size 30 . Melalui penempatan shelter bambu bertingkat sebanyak 75\% luasan kolam (Gambar 2), maka kepadatan tebar benih juga dapat ditingkatkan hingga mencapai $25 \mathrm{ekor} / \mathrm{m}^{2}$. Hasil panen yang diperoleh tersebut tergolong sangat tinggi dibandingkan pada pemeliharaan udang galah dengan bentuk shelter sederhana, dan luas shelter $20 \%$ luasan kolam. Budiman (2004) menyatakan bahwa rata-rata produksi udang galah pada kolam seluas $700--1.000 \mathrm{~m}^{2}$
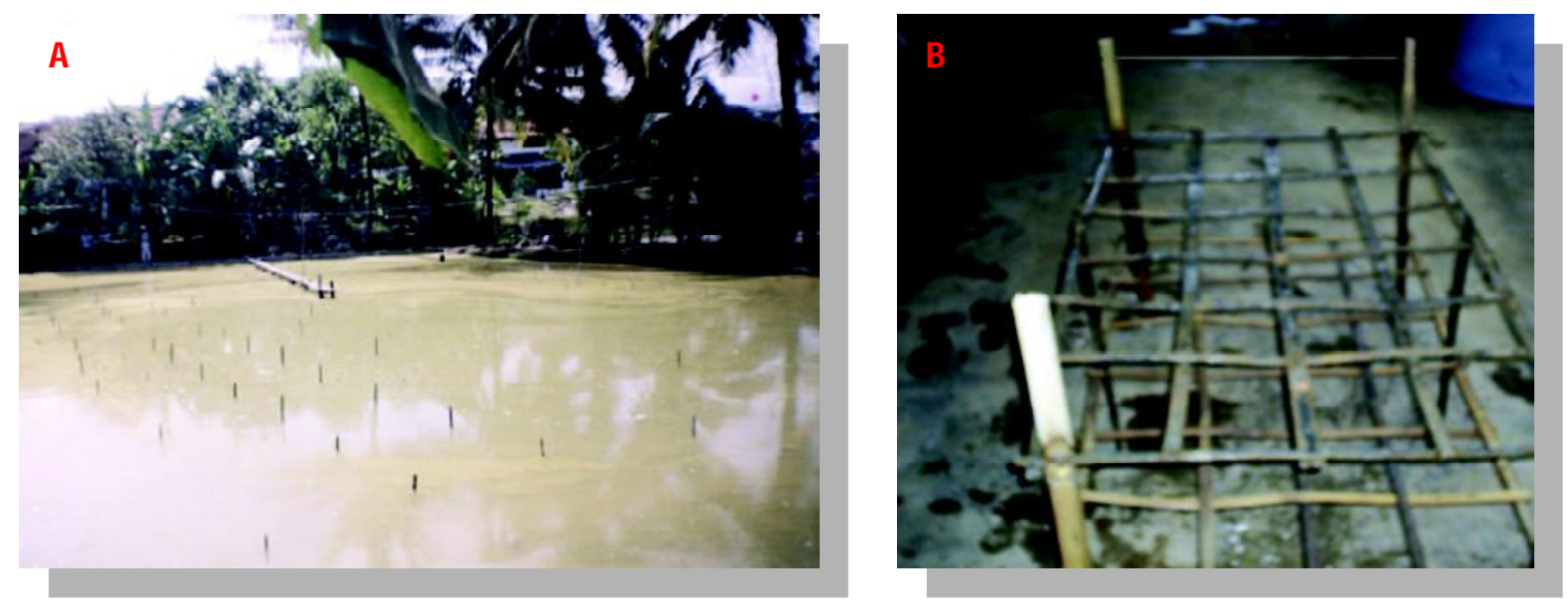

Gambar 2. Kolam udang galah dengan shelter (a) dan tipe shelter bambu bertingkat "appartement shelter" (b) 
baru mencapai 150--250 kg. Menurut Tidwell et al. (2002), penempatan naungan buatan pada kolam pemeliharaan udang galah akan mampu meningkatkan padat penebaran, sehingga produksi yang diperoleh juga meningkat.

\section{MONITORING KUALITAS AIR SECARA PERIODIK}

Kualitas air memegang peranan yang sangat penting bagi kehidupan udang yang dipelihara. Air kolam dikatakan baik apabila mampu menunjang kehidupan ikan atau udang yang dipelihara (Huet, 1979; Boyd, 1976). Timbulnya penyakit pada pemeliharaan udang biasanya diawali dengan kualitas air kolam yang kurang baik. Kondisi tersebut umumnya disebabkan oleh padat penebaran yang terlalu tinggi, dan penggunaan pakan buatan yang kurang tepat. Secara umum, parameter fisika-kimia air yang mempengaruhi kehidupan ikan atau udang meliputi suhu, kesadahan, oksigen terlarut, karbondioksida bebas, $\mathrm{pH}$, kadar amonia, dan nitrit (Boyd, 1981; Cheng et al., 2002; Foss et al., 2003). Tingkat kehilangan pakan (pakan tidak terkonsumsi) yang tinggi menyebabkan kualitas air mengalami penurunan yang cepat, yang ditandai dengan kadar amonia dan nitrit yang tinggi. Untuk mengatasi permasalahan tersebut, maka pergantian air merupakan hal yang harus dilakukan secara rutin, khususnya pada budidaya udang galah skala semi intensif dan intensif. M elalui pergantian air secara rutin, diharapkan kolam terhindar dari akumulasi limbah sisa pakan, yang mengganggu kehidupan udang. Pada pemeliharaan udang secara intensif, kandungan oksigen terlarut yang rendah juga harus dihindari. Beberapa cara dapat ditempuh untuk menciptakan kadar oksigen tinggi, di antaranya dengan menempatkan beberapa kincir, atau memodifikasi air masukan dengan sistem pancuran air (Gambar 3). Menurut Wynne (2000), kondisi optimal untuk pemeliharaan udang galah adalah: suhu air antara $27^{\circ} \mathrm{C}--30^{\circ} \mathrm{C}$, oksigen terlarut minimal $3 \mathrm{mg} / \mathrm{L}$; kesadahan 20--200 mg/L; dan pH 7,0--8,5. Sementara itu, batas kadar amonia $\left(\mathrm{NH}_{3}\right)$ yang aman bagi pertumbuhan udang adalah di bawah 0,1 mg/L. Kadar amonia yang mencapai $0,6 \mathrm{mg} / \mathrm{L}$ dapat mematikan udang dalam waktu singkat (Boyd, 1990).

Melalui pemberian pakan yang tepat serta masukan air yang terjaga diharapkan kualitas air akan tetap terjamin hingga pemeliharaan udang berjalan dua bulan. Apabila kualitas air masih baik, maka penggunaan kincir belum diperlukan. Namun demikian, setelah udang tumbuh mencapai ukuran 10 gram, dengan jumlah pakan yang tinggi, mekanisme suplai oksigen ke air harus dilakukan. Kondisi kualitas air yang kurang baik diindikasikan dengan banyaknya udang yang menempel di pematang kolam atau di atas shelter, khususnya di pagi hari. Dalam kondisi

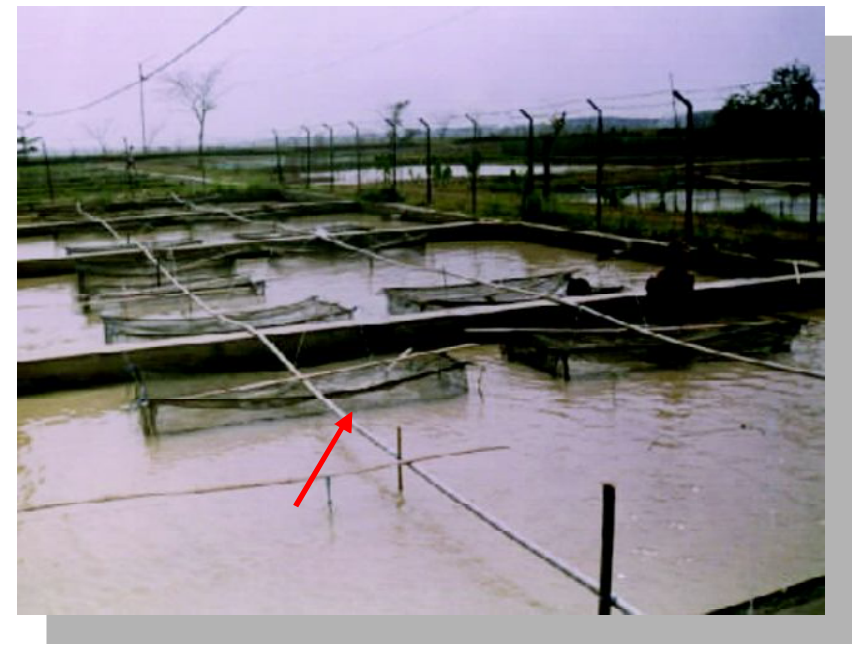

Gambar 3. Kolam pemeliharaan udang galah dengan sistem pancuran air menggunakan pompa submersible, sebagai sarana suplai oksigen

demikian, maka pemasangan kincir air atau sistem air pancuran harus dilakukan.

Monitoring kualitas air bagi pembudidaya dengan luasan cukup besar dapat dilakukan dengan berbagai alat dan indikator kit yang telah ada. M onitoring parameter oksigen terlarut, kadar amoniak, dan nitrit sebaiknya dilakukan setiap hari pada pagi hari. Sementara bagi pembudidaya dengan luasan dan modal terbatas monitoring kelayakan air kolam dapat dilakukan secara sederhana, dengan cara mengamati perilaku udang, serta warna dan bau air, terutama di pagi hari.

\section{PENYERAGAMAN UKURAN DAN MONOSEKS}

Meskipun kita telah menggunakan benih dengan ukuran seragam, namun pada perkembangannya udang yang kita pelihara akan mengalami variasi ukuran. Udang galah jantan biasanya akan cenderung tumbuh lebih cepat dibandingkan betinanya. Kegiatan grading dapat dilaksanakan setelah pembesaran sudah berjalan sekitar dua bulan, di mana udang sudah mencapai ukuran 6--7 g dan cukup mudah untuk dibedakan antara jantan dan betina (Sagi et al., 1985; Dewi et al., 2006). Menurut Tidwell et al. (2002), melalui program size-grading akan diperoleh total panen yang lebih tinggi serta rata-rata berat yang seragam. Program grading juga dilakukan untuk mendapatkan populasi udang dengan kondisi tunggal kelamin (monoseks) jantan. Menurut Sagi et al. (1985), melalui pemeliharaan udang galah tunggal kelamin jantan diperoleh peningkatan total produksi yang cukup besar, yaitu dari $2.500--3.000 \mathrm{~kg} / \mathrm{ha}$ (campur jantan-betina) menjadi $4.700 \mathrm{~kg} / \mathrm{ha}$ (tunggal kelamin jantan) dengan periode pemeliharaan yang sama, yaitu 150 hari. 
Melalui pemeliharaan sistem monoseks kemungkinan diperoleh udang dengan ukuran lebih besar juga akan lebih cepat, sehingga pembudidaya akan memperoleh harga jual udang lebih tinggi. Harga udang galah di pasar lokal untuk ukuran 30--40 gram/ekor adalah Rp 20.000,- Rp 25.000,-, sementara udang dengan ukuran mencapai 75--100 gram (10--15 ekor/kg) bisa mencapai Rp 40.000,-Rp 50.000,--, berdasarkan observasi pasar ikan Kabupaten Karawang, Banyumas, dan Bandung. Secara umum ikan yang dipelihara secara monoseks akan tumbuh lebih cepat, karena energi yang dimiliki akan digunakan secara maksimal untuk pertumbuhan, sementara dalam pemeliharaan campur sebagian energi akan digunakan untuk proses reproduksi.

\section{PENGGUNAAN PAKAN DAN SISTEM PEMBERIAN YANG TEPAT}

Selain memanfaatkan keberadaan pakan alami, selama pemeliharaan udang galah perlu diberikan pakan tambahan, berupa pelet udang dengan kadar protein 28\%-32\% Kesuburan pakan alami sangat dipengaruhi oleh tingkat kesuburan perairan kolam sehingga pemanfaatan pakan alami secara mutlak hanya dapat dilakukan untuk budidaya udang galah dengan kepadatan rendah. Untuk mendapatkan produksi yang maksimal maka penggunaan pakan yang berkualitas dan sistem pemberian yang tepat merupakan prosedur yang harus dijalankan dalam budidaya sistem intensif dan semi intensif (Tidwell et al., 2002). Menurut Wynne (2000), pakan harus diberikan merata keseluruh luasan kolam. Pada pemeliharaan secara monokultur jumlah pakan tambahan yang diberikan sejumlah 20\%pada dua minggu pertama, menurun sampai $5 \%$ dari bobot badan total populasi, dengan frekuensi pemberian 4--5 kali sehari. Sementara itu, pada pemeliharaan secara polikultur jumlah pakan tambahan yang diberikan mulai $6 \%$ menurun sampai $3 \%$ dari bobot badan total populasi, dengan frekuensi pemberian 4--5 kali sehari (Anonim, 2003). Oleh karena sifat makan udang yang lambat maka pakan yang digunakan harus memiliki kestabilan yang tinggi di air, sehingga akan efektif dikonsumsi oleh udang. Untuk mengetahui respon udang terhadap pakan yang diberikan maka penempatan anco di setiap sudut kolam sangat diperlukan. Selain sebagai sarana untuk mengecek efektivitas dan kualitas pakan yang digunakan, anco juga merupakan alat bantu untuk mengetahui kondisi dan ukuran udang.

\section{PENGEMBANGAN SENTRA BUDIDAYA UDANG GALAH}

Keluhan dan perasaan cemas tentang sulitnya mendapatkan harga jual udang yang pantas masih dirasakan oleh banyak pembudidaya udang galah skala kecil. Sedikitnya hasil panen dan produk yang tidak kontinyu merupakan kendala bagi pembudidaya untuk menjual udang yang dipanen ke pengusaha cold storage, yang diharapkan mau membeli udang konsumsi dengan harga tinggi. Di beberapa daerah seperti Kabupaten Subang, Karawang, dan Purwokerto pasar lokal hanya menghargai udang galah sekitar Rp 20.000,-/kg untuk udang dengan ukuran 25--30 gram. Kondisi yang kurang nyaman tersebut perlu segera dicari solusinya, supaya gairah untuk membudidayakan udang galah dapat terus ditingkatkan. Pangsa pasar ekspor yang menjanjikan harga yang tinggi harus lebih ditangani secara serius, yaitu melalui pembinaan secara intensif sampai terbentuknya kelompok pembudidaya dengan penguasaan teknologi budidaya yang baik dan luasan kolam budidaya yang memadai, sehingga mampu menjamin persyaratan cold storage atau eksportir. Iklim budidaya udang galah yang mapan seperti di Jogjakarta dan Bali kiranya perlu dijadikan acuan bagi pengembangan kawasan budidaya udang galah di daerah lain.

\section{PENUTUP}

Peluang untuk meningkatkan produktivitas budidaya udang galah di Indonesia dapat ditempuh melalui beberapa jalur, yaitu intensifikasi dengan penerapan teknologi budidaya yang baik dan ekstensivikasi melalui pengembangan kawasan sentra budidaya udang galah.

\section{DAFTAR PUSTAKA}

Alimon, S. 2005. Pond preparation and water management. Malaysia Technical Cooperation Programmed. Departement of Fisheries, Ministry of Agriculture and Agro-Based Industry. Malaysia. 16 pp.

Anonim. 2003. Teknik Pembesaran Udang Galah (Macrobrachium rosenbergii de Man) Informasi Teknologi. Balai Budidaya Air Tawar Sukabumi. Departemen Kelautan dan Perikanan Republik Indonesia. $10 \mathrm{pp}$.

Boyd, C.E. 1981. Water Quality in Warm Water Fish Pond. Auburn University. Auburn-Alabama. 358 pp.

Boyd, C.E. 1990. Water quality in pond for aquaculture. Birmingham Publishing Company, Alabama. 147 pp.

Budiman A. A. 2004. Perkembangan Udang GIMacro di Indonesia. Temu Nasional Udang Galah GIMacro di Jogjakarta, 22-23 Juni 2004. 11 pp.

Cheng ,W., Su-Mei Chen, Feng-I Wang, Pei-I Hsu, ChunHung Liu, and Jiann-Chu Chen. 2002. Effect of temperature, $\mathrm{pH}$, salinity and ammonia on the phagocytic and clearance efficiency of giant freshwater 
prawn Macrobrachium rosenbergii to Lactococcus garvieae. Aquaculture. 219: 111-121.

Dewi, R.R.S.P.S., I. Khasani, Sularto, and W. Pamungkas. 2006. Production of female giant freshwater prawn (Macrobrachium rosenbergii) through hormonal induction. Indonesian Aquaculture Journal. 1(1): 3538.

Foss, A., T. Vollen, and V. Oiestad. 2003. Growth and oxigen consumption in normal and $\mathrm{O}_{2}$ supersaturated water, and interactive effects of $\mathrm{O}_{2}$ saturation and ammonia on growth in spotted wolfish (Anarhichas minor Olafsen). Aquaculture. 224: 105- 116.

Hadie, W. and L.E. Hadie. 1997. Hilangnya benih dalam budidaya udang galah (Macrobrachium rosenbergii) dan dugaan faktor penyebabnya. W. Pen. Perik. Indonesia. Pusat Penelitian dan Pengembangan Perikanan. p. 17- 21.

Huet, M. 1979. Text Book of Fish Culture Breeding and Cultivation of Fish. Fishing news. London. 436 pp.

Khasani, I. 2004. Peningkatan produksi massal benih udang galah GiMacro. Laporan Hasil Penelitian. Loka Riset Pemuliaan dan Teknolohi Budidaya Perikanan Air Tawar, Sukamandi. 7 pp.
Mente, E. 2003. Nutrition, physiology, and metabolism of crustaceans. Science Publisher, inc, Enfield. 126 pp.

New, M.B. 2002. Farming freshwater prawn, a manual for the culture of giant river prawn (Macrobrachium rosenbergii ). FAO Fisheries Technical Paper, Rome. $207 \mathrm{pp}$.

New, M.B. and W.C. Valenti. 2004. Freshwater prawn culture: The farming of Macrobrachium rosenbergii. Blackwell Science, Oxford. 435 pp.

Sagi, A., Z. Ra'anan, Cohen, and Y. Wax. 1985. Production of Macrobrachium rosenbergii in monosex opulations: Yield characteristics under intensive monoculture condition in cages. Elsevier Science Publisher B.V., Amsterdam. p. 32- 40.

Tidwell, J.H., S. Coyle, M.R. Durborow, S. Dasgupta, and W.A. Wurts. 2002. The Malaysian Freshwater Prawn. The Kentucky State University Aquaculture Program. $45 \mathrm{pp}$.

Wynne, F. 2000. Grow-out culture of freshwater prawn in Kentucky. Kentucky State University Cooperative Extension Program, Graves Country Cooperative Extension Service. 9 pp. 